\title{
Investigating strengths and deficits to increase work engagement: A longitudinal study in the mining industry
}

\begin{tabular}{|c|c|}
\hline \multicolumn{2}{|c|}{ 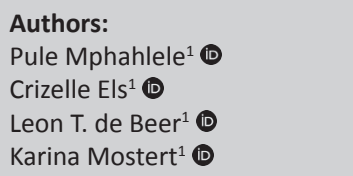 } \\
\hline \multicolumn{2}{|c|}{$\begin{array}{l}\text { Affiliations: } \\
{ }^{1} \text { WorkWell Research Unit for } \\
\text { Economic and Management } \\
\text { Sciences, North-West } \\
\text { University, South Africa }\end{array}$} \\
\hline \multicolumn{2}{|c|}{$\begin{array}{l}\text { Corresponding author: } \\
\text { Crizelle Els, } \\
\text { crizelle.els@nwu.ac.za }\end{array}$} \\
\hline \multicolumn{2}{|c|}{$\begin{array}{l}\text { Dates: } \\
\text { Received: } 14 \text { Dec. } 2016 \\
\text { Accepted: } 06 \text { Oct. } 2017 \\
\text { Published: } 27 \text { Feb. } 2018\end{array}$} \\
\hline \multicolumn{2}{|c|}{$\begin{array}{l}\text { How to cite this article: } \\
\text { Mphahlele, P., Els, C., De } \\
\text { Beer, L.T., \& Mostert, K. } \\
\text { (2018). Investigating } \\
\text { strengths and deficits to } \\
\text { increase work engagement: } \\
\text { A longitudinal study in the } \\
\text { mining industry. SA Journal of } \\
\text { Human Resource } \\
\text { Management/SA Tydskrif vir } \\
\text { Menslikehulpbronbestuur, } \\
\text { 16(0), a900. https://doi. } \\
\text { org/10.4102/sajhrm. } \\
\text { v16i0.900 }\end{array}$} \\
\hline \multicolumn{2}{|c|}{$\begin{array}{l}\text { Copyright: } \\
\text { (c) 2018. The Authors. } \\
\text { Licensee: AOSIS. This } \\
\text { is licensed under the } \\
\text { Creative Commons } \\
\text { Attribution License. }\end{array}$} \\
\hline \multicolumn{2}{|l|}{ Read online: } \\
\hline 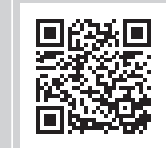 & $\begin{array}{l}\text { Scan this QR } \\
\text { code with your } \\
\text { smart phone or } \\
\text { mobile device } \\
\text { to read online. }\end{array}$ \\
\hline
\end{tabular}

Orientation: The motivational process of the Job Demands-Resources (JD-R) model indicates that job resources are the main predictors of work engagement. Previous research has found that the two job resources perceived organisational support (POS) for strengths use and POS for deficit correction are also positively related to work engagement. However, the causal relationships between these variables have not been investigated longitudinally.

Research purpose: To determine if POS for strengths use and POS for deficit correction are significant predictors of work engagement over time.

Motivation for the study: In the literature, empirical evidence on the longitudinal relationships between work engagement and specific job resources, namely POS for strengths use and POS for deficit correction, is limited.

Research design, approach and method: A longitudinal design was employed in this study. The first wave elicited a total of 376 responses, while the second wave had a total sample size of 79. A web-based survey was used to measure the constructs and to gather data at both points in time. Structural equation modelling was used to investigate the hypotheses.

Main findings: The results indicated that both POS for strengths use and POS for deficit correction are positively related to work engagement in the short term. However, only POS for deficit correction significantly predicted work engagement over time.

Practical and managerial implications: The results provide valuable insights to organisations by providing knowledge regarding which approach influences work engagement levels of their employees in the short and long term.

Contribution or value-add: The study contributes to the limited research on what job resources predict work engagement over time.

\section{Introduction}

It is evident that the mining industry is facing a challenging crisis, globally as well as in South Africa. To gain investor confidence, organisations in the industry have to remain competitive and maximise the value of existing assets (Jamasmie, 2015). This is a tough challenge, considering the unavoidable necessity to respond to the drop in commodity prices, rising production costs and volatile working environments (Deloitte, 2016; Jamasmie, 2015; KPMG, 2016; PwC, 2014). As part of the response to the above-mentioned challenges, one of the assets on which organisations can maximise value is their employees, who can be trained and developed for optimal functioning (Salas, Tannenbaum, Kraiger \& Smith-Jentsch, 2012). This strategy to achieve a competitive advantage through employees has been well researched and proven to be effective by numerous authors over the years (Barney, 1991; De Pablos \& Lytras, 2008; Jassim \& Jaber, 1998; Wright, McMaham \& McWilliams, 1994).

In the past, studies on the concept of training and developing employees have been centred on the notion of improving or overcoming weaknesses or deficiencies (Goaverts, Kyndt, Dochy \& Baert, 2011; Linley \& Harrington, 2006). Practically, this has translated to employee shortcomings being identified and subsequently addressed through development initiatives. According to Noe (2010), the deficit approach has been well entrenched in various organisations for several decades. In addition, some organisations utilise the development approach to stay abreast of the changing world of work by continually encouraging employee learning attainment and transference to ensure sustainable success and a competitive advantage (Barney, 2002; Bassi, Ludwig, McMurrer 
\& Van Buren, 2000; Noe, 2010). Furthermore, numerous other studies on the deficit approach have provided scientific evidence of the positive outcomes from an organisational perspective. Salas et al. (2012) have found that higher levels of work engagement can be achieved when organisations support a deficit improvement approach. Similarly, Benson (2006) and Tansky and Cohen (2001) have discovered that organisational commitment is obtained through following this approach. Other outcomes of a deficit correction approach include higher job satisfaction and lower turnover intention (Lee \& Bruvold, 2003), as well as increased performance (Abdullah, Ahsan \& Alam, 2009, Anguinis \& Kraiger, 2009).

The benefits resulting from the deficit improvement approach do however not escape criticism. Kretzmann and Mcknight (1993) have criticised that, as an intervention, it is reactive, as the problem would already be in existence. This has led to the study of more proactive approaches that focus on building what is already going right within organisations. This shift in paradigm occurred with the emergence of the positive psychology movement, where the focus is on what assists people to flourish, excel, experience flow and function optimally, as opposed to mainly focusing on improving their weaknesses (Linley, Joseph, Harrington \& Wood, 2006).

Later on, the positive psychology paradigm was supported by the study on strengths, made prominent by Marcus Buckingham, which purports that people grow most in their areas of strengths (Buckingham \& Clifton, 2001). This movement fuelled various other research studies on the application and use of strengths within the workplace and, subsequently, positive organisational outcomes have been attributed to the strengths approach. Various studies have shown that work engagement is one of the positive outcomes of the use of strengths (Botha \& Mostert, 2014; Harter, Schidt \& Hayes, 2002; Harzer \& Ruch, 2012, 2013; Keenan \& Mostert, 2013; Linley \& Harrington, 2006; Stander, Mostert \& De Beer, 2014; Van Woerkom, Oerlemans \& Bakker, 2015). In addition, Clifton and Harter (2003) have indicated that productivity increases for employees who use their strengths. Organisational commitment was also found to be linked with the use of strengths within the organisation (Biswas-Diener, Kashdan \& Minhas, 2011).

It is clear that there are positive organisational outcomes associated with both the deficit and strengths-based approaches. It therefore seems important to investigate the effect of both these approaches, not only one or the other, on important organisational outcomes. Indeed, recent studies investigating the contextual dependency of both approaches have emerged (Rust, Diessner \& Reade, 2009; Van Woerkom et al., 2016). More specifically, Van Woerkom et al. (2016) reason that it is important for an organisation to be supportive of employees to use their strengths and improve or overcome their weaknesses. These authors argue that positive organisational outcomes are a result of employees who perceive their organisations to be supportive of them using their strengths (perceived organisational support [POS] for strengths use) and improving their deficits (POS for deficit correction) (Van Woerkom et al., 2016).

Drawing on the arguments by Van Woerkom et al. (2016), the question arises as to what extent POS for strengths use and POS for deficit correction contribute to employee outcomes, specifically work engagement. Work engagement has been linked to bottom-line outcomes (Bakker, Albrecht \& Leiter, 2011; George, 2010), is fundamentally a motivational concept and has been proven to have a positive effect on employee commitment and motivation (Sonnentag, 2011). In addition, researchers have indicated that there are organisations that leverage on employees with high levels of work engagement to create a competitive advantage (Christian, Garza \& Slaughter, 2011; Macey \& Schneider, 2008; Rich, LePine \& Crawford, 2010).

Ample research on the antecedents of work engagement is available both locally (De Braine \& Roodt, 2011; Mostert, Cronjé \& Pienaar, 2006; Olivier \& Rothmann, 2007; Rothmann \& Jordaan, 2006) and internationally (Bakker, Demerouti \& Euwena, 2005; Hakanen, Bakker \& Schaufeli, 2006; Llorens, Schaufeli, Bakker \& Salanova, 2007). Recently, studies have also started to focus on the effect of strengths use and deficit correction (SUDCO) on engagement (Botha \& Mostert, 2014; Els, Mostert \& Van Woerkom, 2015; Keenan \& Mostert, 2013; Stander et al., 2014; Van Niekerk, Mostert \& De Beer, 2016; Van Woerkom et al., 2016). These studies confirmed the predictive value of both SUDCO on engagement. However, all these studies were cross-sectional designs and therefore cannot determine whether there is a longitudinal relationship between SUDCO and work engagement, and cannot also make causal inferences.

As previously indicated, given the grave challenges that mining organisations face, the industry presents a significant context for the study of work engagement and how it can be improved. In a study conducted in the mining sector by Rothmann and Joubert (2007), organisational support (in the form of managerial support, communication, role clarity and the extent of work autonomy) was found to be a significant predictor of work engagement. Similarly, other forms of job resources (supervisor support and co-worker support) showed a positive relationship with work engagement in the platinum mining environment (Palo \& Rothmann, 2016). While studies in various sectors have concluded positive organisational outcomes associated with POS for strength use and POS for deficit correction, these constructs have not been explored within the mining industry.

This study aims to add to the body of literature from a longitudinal perspective on the relationship between POS for strengths use, POS for deficit correction and work engagement over time in a two-wave study within the mining industry. Consequently, the objective of this article is to determine if POS for strengths use and POS for deficit correction are significant predictors of work engagement over time. 


\section{Literature review}

\section{Perceived organisational support for strengths use and deficit correction}

In their study, Eisenberger, Huntington, Hutchison and Sowa (1986) concluded that employees develop global beliefs about how their organisations value their contributions and show care for their well-being. The authors derived the concept of POS, which explains the extent to which employees perceive that their organisations care for their well-being and value their contributions. Appropriating from the social exchange theory of Blau (1964), as well as the norm of reciprocity (Gouldner, 1960), POS theory suggests that as perceived support from the organisations increases for employees, an increase and strengthening of organisational commitment is highly probable (Eisenberger, Armeli, Rexwinkel, Lynch \& Rhoades, 2001). This finding is supported by other studies, which have linked POS to other positive organisational outcomes, such as job satisfaction (Aquino \& Griffeth, 1999; Shore \& Tetrick, 1991), lower turnover intention, stress and withdrawal behaviour (Rhoades \& Eisenberger, 2002) and work engagement (Rich et al., 2010; Saks, 2006).

On the basis of the organisational support theory, Van Woerkom et al. (2016) derived the concepts of POS for strengths use and POS for deficit correction. POS for strengths use is defined as the extent to which employees perceive and believe that their organisations support the use and application of their strengths within the workplace (Van Woerkom et al., 2016). Practically, that translates to organisations having human resources (HR) practices that allow for and encourage employees to utilise their strengths at work. According to Linley et al. (2006), strengths are a combination of talents (naturally recurring patterns of thoughts, feelings and behaviour), knowledge (facts and lessons learned) and skills. Buckingham (2007), on the other hand, explains that strengths are activities that are energising and performed with effortless excellence. As previously discussed, numerous positive organisational outcomes are associated with the use of strengths within the workplace, such as job satisfaction (Peterson, Stephens, Park, Lee \& Seligman, 2009), organisational commitment (Biswas et al., 2011) and work engagement (Botha \& Mostert, 2014; Harzer \& Ruch, 2012, 2013; Stander et al., 2014; Van Woerkom et al., 2015).

With regard to deficits, Van Woerkom et al. (2016) argue that employees also rely on the support from the organisation to improve and develop their deficits. They define POS for deficit correction as the extent to which employees perceive and believe that their organisations support them to improve their deficits or weaknesses in the workplace.

The word 'deficit', according to Oxford English Dictionary (2017), is derived from the Latin word deficere, which means 'it is lacking'. In the workplace, the common language to describe this is 'weakness', which implies a personal defect or failing (Oxford English Dictionary, 2017), which relates to skills, knowledge and behaviour that are not fully developed according to a set standard. Traditionally, employee development in organisations was fundamentally from a deficit improvement perspective. Well-entrenched HR processes such as coaching, performance appraisals, training and so forth can give testimony to that, where set performance standards are used as a benchmark to which employees should comply with (Linley \& Harrington, 2006). As previously discussed, there are positive organisational outcomes that are linked to the deficit improvement approach, which include organisational commitment (Bartlett, 2001), job satisfaction (Schmidt, 2007), decrease in turnover intention (Pfeffer \& Sutton, 2006) and work engagement (Bakker \& Geurts, 2004).

\section{Perceived organisational support for strengths use and perceived organisational support for deficit correction in the framework of the Job Demands-Resources model}

One theory that is often used to explain the motivational process of work engagement is the Job Demands-Resources (JD-R) model. The fundamental assumption of this model is that every occupation has its own sources of employee wellbeing and these can be classified into two categories, job demands and job resources (Bakker \& Demerouti, 2007; Demerouti, Bakker, Nachreiner \& Schaufeli, 2001). Demerouti and Bakker (2011) further explain that the JD-R model is applicable to various occupational settings regardless of the demands and resources present.

\section{Job demands refer to those:}

physical, psychological, social, or organisational aspects of the job that require sustained physical and/or psychological (cognitive and emotional) effort or skills and are therefore associated with certain physiological and/or psychological costs. (Bakker \& Demerouti, 2007, p. 312)

Typical examples of job demands could be unfavourable working conditions, work overload, strict deadlines, and cognitive and emotional demands. Job resources, on the other hand, are defined as:

those physical, social, or organisational aspects of the job that may do any of the following: (1) be functional in achieving work goals; (2) reduce job demands and the associated physiological and psychological costs; (3) stimulate personal growth and development. (Bakker \& Demerouti, 2007, p. 312)

Typical examples include autonomy, social support, career opportunities and role clarity.

One of the main assumptions of the JD-R model is that there are two underlying processes: a health impairment process and a motivational process. When there is not enough time to recover or recuperate from one's job demands, this could lead to mental and/or physical exhaustion, such as burnout, and eventually ill-health symptoms (Bakker et al., 2005). This is known as the health impairment process. The motivational process implies that job resources mitigate the negative effects of job demands and may lead to increased work engagement, and eventually positive organisational 
outcomes, such as organisational commitment (Bakker, Demerouti, Taris, Schaufeli \& Schreurs, 2003).

As stated earlier, the motivational process of the JD-R model implies that work engagement is positively influenced by job resources, such as autonomy, social support and role clarity (Bakker et al., 2003, 2005; Bakker, Hakanen, Demerouti \& Xanthopoulou, 2007). This has encouraged other researchers to discover other possible job resources within the work environment. Van Woerkom et al. (2016) conceptualise POS for strengths use and POS for deficit correction as specific forms of job resources. According to these authors, POS for strengths use can be classified as a job resource as it creates an environment that affords employees the opportunity to apply their potential and full capacity (strengths) to achieve organisational goals (Demerouti \& Bakker, 2011; Van Woerkom et al., 2016). The application and use of strengths in the workplace have been attributed to higher levels of work engagement (Harter et al., 2002), increased job satisfaction (Peterson et al., 2009) as well as an increase in organisational commitment (Biswas-Diener et al., 2011). Similarly, Van Woerkom et al. (2016) describe POS for deficit correction as a job resource. Training and development initiatives, over the years, have been attributed to enhancing organisational performance and delivering positive results (Arthur, Bennett, Edens \& Bell, 2003; Keith \& Frese, 2008; Morris \& Robie, 2001). Tansky and Cohen (2001) have discovered that the deficit approach leads to increased organisational commitment by employees. Lee and Bruvold (2003), on the other hand, have associated the development of deficits with an increase in job satisfaction, while Schaufeli and Bakker (2004) have recorded higher levels of work engagement.

Based on the definition of job resources according to the JD-R model, it is clear that both POS for strengths use and POS for deficit correction (1) assist in the achievement of work goals, (2) assist in dealing with job demands and (3) stimulate the personal growth and development of employees. In addition, both POS for strengths use and POS for deficit correction activate similar motivational processes as do other job resources, with positive outcomes such as the ones described above.

\section{Relationships between perceived organisational support for strengths use and perceived organisational support for deficit correction and work engagement}

Work engagement is a well-researched topic in the field of industrial psychology. It is defined as a 'positive, fulfilling, work-related state of mind that is characterised by vigour, dedication, and absorption' (Schaufeli \& Bakker, 2004, p. 295). Vigour refers to high levels of energy that one devotes to one's work, and the ability to face challenges without losing energy. Dedication refers to a strong identification with one's work. Emotions such as pride, enthusiasm and inspiration are experienced. Absorption refers to the state where an employee is immersed in his or her work under the perception that time flows rapidly (Schaufeli \& Bakker, 2004). Some researchers have indicated that vigour and dedication comprise the core dimensions of work engagement. Absorption on the other hand has been equated to flow by some researchers (González-Roma, Schaufeli, Bakker \& Lloret, 2006; Langelaan, Bakker, Van Doornen \& Schaufeli, 2006), and as a consequence of work engagement (Schaufeli \& Bakker, 2004). Therefore, several studies only include the two core dimensions of vigour and dedication.

Research on work engagement suggests a win-win situation for both employer and employee. For the organisation, work engagement is positively related to customer satisfaction (Salanova, Agut \& Peiró, 2005), financial returns (Xanthopoulou, Bakker, Demerouti \& Schaufeli, 2009) and attaining and maintaining a competitive advantage (Bakker, Schaufeli, Leiter \& Taris, 2008). For employees, work engagement has been associated with good health and a positive work affect (Demerouti, Bakker, De Jonge, Janssen \& Schaufeli, 2001) as well as with in-role performance (Schaufeli, Taris \& Bakker, 2006).

Given several studies that prove that job resources are the main predictors of work engagement, it is therefore expected that both POS for strengths use and POS for deficit correction lead to increased levels of work engagement. In studies conducted by Botha and Mostert (2014) and Stander and Mostert (2013), POS for strengths use was found to have a significant positive relationship with work engagement. This is consistent with Buckingham's (2007) conclusion that those activities completed from a strengths approach are energising and will be performed with excellence, which practically can be less time-consuming. As a result, it is expected that employee performance and engagement levels will increase.

From an extrinsic motivational perspective, POS for strengths use creates a work environment where employees can utilise their potential, abilities and efforts to accomplish and execute their work tasks well (Demerouti \& Bakker, 2011; Van Woerkom et al., 2016). In support of this, Biswas-Diener (2010) explains that employees who apply their strengths feel more energised and may derive fulfilment from their jobs. Linley and Harrington (2006) also found a positive relationship between strengths use and psychological state of fulfilment and satisfaction about employees' abilities. This creates feelings that may lead to increased levels of work engagement. It is therefore expected that a significant positive relationship will exist between POS for strengths use and work engagement (Hypothesis 1a).

With regard to POS for deficit correction, organisations that support employees to rectify their weaknesses can minimise and, in some cases, also eliminate any skills and/or behaviour that do not facilitate the attainment of business goals (Smits, Van Woerkom \& Van Engen, 2012). Various studies have positively correlated deficit correction with levels of work engagement (Metz, Burkhauser \& Bowie, 2009; Salas et al., 2002). In addition, factors such as feelings of employability (implying that employees can remain attractive for current and future organisations) (Rothwell \& Arnold, 2007) and 
career advancement (because of improving their skills sets for current and future roles) (Benson, 2006) can contribute to increased levels of work engagement. Furthermore, as the work performance of employees improves (because of weaknesses being addressed), employees may experience well-being and subsequently increased levels of work engagement (Abdullah et al., 2009).

Research studies have also indicated that employees who are offered an environment that fosters growth and learning are likely to experience higher levels of work engagement (Bakker \& Geurts, 2004), feel valued (Metz et al., 2009) and are motivated (Salas et al., 2002). The motivational role played by POS for deficit correction can be extrinsic and intrinsic in nature because it fosters learning and personal growth as well as assists in the achievement of tasks (Bakker \& Demerouti, 2007). The intrinsic motivational nature of job resources is also in line with Deci and Ryan's selfdetermination theory (Deci \& Ryan, 1985), which explains that job resources fulfil basic human needs, such as autonomy, competence and relatedness. Based on this reasoning, it is expected that POS for deficit correction will have a significant positive relationship with work engagement (Hypothesis 1b).

\section{Relationships between perceived organisational support for strengths use and perceived organisational support for deficit correction and work engagement over time}

Over the years, work engagement research has shown that the construct is stable, permanent and long lasting (Hakanen, Peeters \& Perhoniemi, 2011; Schaufeli, Bakker \& Van Rhenen, 2009). However, several studies have indicated that job resources are positively related to work engagement over time and, furthermore, discovered that there exists a reciprocal causal relationship present, where job resources predict work engagement, which in turn predicts job resources over time (Mauno, Kinnunch, Mäkikangas \& Feldt, 2010; Simbula, Guglielmi \& Schaufeli, 2011; Xanthopoulou et al., 2009).

In a study by Hakanen, Schaufeli and Ahola (2008), the authors found that the motivational process of the JD-R model was supported over a 3-year wave period. It was explicitly established that job resources predicted work engagement among Finnish dentists over time. In another study by Mauno, Kinnunen and Ruokolainen (2007), the longitudinal relationship between job resources and work engagement was confirmed among Finnish public workers in a 2-year period. Lastly, within the educational context, Llorens et al. (2007) found significant longitudinal relationships between job resources and work engagement among university students. De Lange, De Witte and Notelaers (2008) explained the underlying mechanisms between the constructs by making reference to the broaden-and-build theory of positive emotions (Fredrickson, 2001).

According to the broaden-and-build theory, positive emotions have the ability to broaden people's thought action behavioural habits and build enduring personal resources that help them cope with and understand their environments better. It is through this process that individuals are able to transform and become more knowledgeable, creative and resilient, which can have a positive impact on their psychological and emotional well-being over time (Fredrickson, 1998, 2001, 2004). In line with the broaden-andbuild theory, De Lange et al. (2008) argue that work engagement (which is a positive emotion) has the capacity to broaden one's thought action patterns and increase and/or build more job resources. Through this process, engaged employees can better mobilise their job resources, which might have an increase in their capability to regulate their emotions (De Lange et al., 2008; Hobfoll, 2001).

Based on the above studies and the inherent nature of POS for strengths use and POS for deficit correction as job resources and the inherent nature of work engagement as a positive emotion, it is therefore expected that there will be a significant and positive relationship over time between POS for strengths use and work engagement (Hypothesis 2a) and also a significant and positive relationship over time between POS for deficit correction and work engagement (Hypothesis 2b).

\section{Research design The research approach}

A quantitative approach was followed by the researcher to conduct the study. To determine the relationship between POS for strengths use and POS for deficit correction over time, a longitudinal two-wave research design was utilised. Menard (2002) defines this research design approach as one where participant outcomes are collected at multiple followup times.

\section{Research participants}

A convenience sampling strategy within a mining organisation in South Africa was utilised. Geographically, participants were surveyed from across Gauteng, Limpopo and the Northern Cape provinces and consisted of employees on supervisory job levels and higher to ensure access to computers and the Internet in order to complete the online survey. An important requirement was that the participants have a good command of English and good literacy levels. The characteristics of the participants are presented in Table 1.

In total, 376 respondents completed the first wave, which resulted in a response rate of $47 \%$. In the first wave, the total number of male respondents was $254(67.55 \%)$ and that of female respondents was $122(32.45 \%)$. This is representative of the male-dominated nature of the mining industry in South Africa. The sample was highly educated, where $48.41 \%$ of participants finished university degrees and/or a postgraduate degree. 
TABLE 1: Characteristics of the participants.

\begin{tabular}{|c|c|c|c|c|c|}
\hline \multirow[t]{2}{*}{ Item } & \multirow[t]{2}{*}{ Category } & \multicolumn{2}{|c|}{ Wave 1} & \multicolumn{2}{|c|}{ Wave 2} \\
\hline & & Frequency & $\%$ & Frequency & $\%$ \\
\hline \multirow[t]{2}{*}{ Gender } & Female & 122 & 32.45 & 33 & 41.77 \\
\hline & Male & 254 & 67.55 & 46 & 58.23 \\
\hline \multirow[t]{5}{*}{ Ethnicity } & Black & 128 & 34.04 & 11 & 13.92 \\
\hline & White & 201 & 53.46 & 58 & 73.42 \\
\hline & Mixed race & 26 & 6.91 & 5 & 6.33 \\
\hline & Asian & 17 & 4.52 & 5 & 6.33 \\
\hline & Other & 7 & 1.86 & 0 & 0.00 \\
\hline \multirow[t]{7}{*}{ Education } & Grade 10 & 7 & 1.86 & 0 & 0.00 \\
\hline & Grade 11 & 2 & 0.53 & 0 & 0.00 \\
\hline & Grade 12 & 73 & 19.41 & 15 & 18.99 \\
\hline & Technical diploma & 55 & 14.63 & 11 & 13.92 \\
\hline & Technicon diploma & 54 & 14.36 & 11 & 13.92 \\
\hline & $\begin{array}{l}\text { University degree } \\
\text { (e.g. BA, BCom) }\end{array}$ & 77 & 20.48 & 12 & 15.19 \\
\hline & $\begin{array}{l}\text { Postgraduate degree } \\
\text { (Honours, Masters) }\end{array}$ & 105 & 27.93 & 30 & 37.97 \\
\hline
\end{tabular}

The second wave of results resulted in a total common sample of 79 participants who completed the survey at wave 1 and wave 2 (response rate from wave 1 to wave 2 was $21.01 \%$ ). Therefore, the 79 participants in the second wave are those participants whose unique individual identification codes from wave 1 matched with those of wave 2 . The mean age of these 79 employees was 44.41 years (standard deviation [SD] $=9.35$ ). In terms of gender, the total male respondents represented $58.23 \%$ of the population, while female respondents represented $41.77 \%$. The percentage of employees who held a university degree and/or a postgraduate degree was $53.16 \%$.

\section{Research procedure}

The questionnaire took approximately $30-45 \mathrm{~min}$ to complete. Participants were given a time period of 2 weeks to complete the questionnaires on both occasions. A reminder was sent electronically to remind the participants of the submission date. The hypotheses were tested in a two-wave longitudinal study with a time lag of 3 months. Data were collected by means of a web-based survey, with a link to the web-based survey sent to the participants via their work e-mail addresses. For the first wave the questionnaire was sent in July and data for the second wave were collected in October 2015 (3 months apart). Individual-level identification codes were used for the participants to ensure continuity in the second wave and to anonymously link the data from time 1 and time 2. The code design was as follows: gender (e.g. female), year of birth (e.g. 1982), number of brothers (e.g. 1), number of sisters (e.g. 1) and first initial of mother's name (e.g. H for Helen) - an example is F198211H.

\section{Measuring instruments}

\section{Biographical characteristics}

Biographical characteristics such as year of birth, gender, ethnicity, education level, work experience, time in current role and work site were measured by means of a biographical questionnaire.
Perceived organisational support for strengths use and deficit correction

Perceived organisational support for strengths use and POS for deficit correction were measured using an adapted version of the SUDCO questionnaire developed by Van Woerkom et al. (2016). This is a tool that scores on a sevenpoint Likert-type frequency scale, ranging from 0 (almost never) to 6 (almost always). POS for strengths use was measured with five items (e.g. 'This organisation uses employees' strengths'). Van Woerkom et al. (2016) report a Cronbach's alpha coefficient of 0.96 for this dimension. POS for deficit correction, on the other hand, was measured with six items of which 'In this organisation, employees receive training to improve their weak points' is an example. The Cronbach's alpha coefficient for POS for deficit correction was reported as 0.93 (Van Woerkom et al., 2016).

\section{Work engagement}

Work engagement was measured by means of the Utrecht Work Engagement Scale (UWES-9) (Schaufeli, Salanova, Gonzalez-Roma \& Bakker, 2002). Work engagement was measured as a single latent variable based on the items of the three dimensions (vigour, dedication and absorption), totalling nine items. Three items measured vigour (e.g. 'At work, I feel like I am bursting with energy'). Dedication was also measured by means of three items: an example includes 'I am enthusiastic about my job'. Lastly, absorption was measured with three items (e.g. 'When I am working, I forget everything else around me'). Work engagement is measured on a seven-point Likert scale ranging from 0 (never) to 6 (everyday). Recent research within South Africa has confirmed work engagement as a one-factor structure, especially when using the UWES-9 (e.g. De Bruin \& Henn, 2013; Smidt, De Beer, Brink \& Leiter, 2016).

\section{Statistical analysis}

\section{Time 1: Measurement model}

Statistical analysis was conducted using Mplus 7.3 (Muthén \& Muthén, 2015). To measure the degree of linear dependence between the variables, Pearson's product-moment correlation ( $r$ ) was used. In addition, effect sizes to determine the practical significance were utilised. According to Cohen (1988), cut-off points of 0.30 (medium effect) and 0.50 (large effect) are used to determine the practical significance of the correlation coefficients. The confidence interval (CI) level for statistical significance was set at a value of $95 \%(p \leq 0.05)$.

Confirmatory factor analysis (CFA) was used to determine the factorial validity (Brown, 2015). To calculate the model's goodness of fit, the following fit indices were considered: comparative fit index (CFI), Tucker-Lewis index (TLI), root mean square error of approximation (RMSEA) and standardised root mean square residual (SRMR). Guidelines on the cut-off points values according to Lance, Butts and Michaels (2006) are as follows: CFI (between 0.90 and 0.99), TLI (between 0.90 and 0.99), RMSEA (between 0.01 and 0.08) and SRMR (between 0.01 and 0.08) (cf. Van de Schoot, Lugtig \& Hox, 2012). 


\section{Time 2: Longitudinal evidence}

Firstly, a measurement model was specified with CFA and maximum likelihood estimation based on the common sample at both points in time. The items were parameterised (labelled) in Mplus to indicate that these were the same items at both time points. This inherently assumes measurement invariance between the two time points between the items. For model fit, the following fit statistics were considered: CFI, TLI, RMSEA and SRMR.

Given an adequate measurement model according to the fit indices, the factor scores for this model were exported for further analysis with Bayesian estimation in a structural model. Factor scores lessen the number of parameters in the structural model and because of the scale of missingness at time 2 ( $n=79$; time 2; common sample). This was deemed necessary to establish longitudinal evidence. Moreover, Bayesian estimation has been shown to handle small samples quite well because of its iterative process (Kosowski, Naik \& Teo, 2007; Scheines, Hoijtink \& Boomsma, 1999). It was decided that evidence for longitudinal relationships between the variables would be considered with this estimation process, because maximum likelihood was unable to estimate this structural model accurately. Bayesian modelling allows for the use of priors specification in models (i.e. information about parameters from past studies or experts). Priors can be non-informative (diffuse) or informative (Muthén, 2010). For this estimation, informed priors were used to inform the final structural model, that is, the loadings and intercepts from time 1 were specified as prior information for the estimation at time 2 with a variance to this prior (see Table 2 for unstandardised loadings and intercepts used to inform the model at time 2).

Bayesian modelling does not present the same fit statistics as is normally expected (e.g. CFI) but models the need to satisfy convergence criterion in the iterative process. Specifically, 25000 iterations were specified for this structural model, and for the convergence criterion, the potential scale reduction factor (PSR), the default value in Mplus at PSR < 1.05 was considered (Muthén, 2010). Furthermore, it is important to consider chain mixing in the Markov chain Monte Carlo (MCMC) chains specified. The default chains in Mplus are set to 2 (i.e. two separate processors for estimation). Basically, what this diagnostic entails is to visually inspect the chain mixing (see Figure 1) in the estimation process, that is, if the two chains at some point converge and provide similar estimates and continue doing so, then chain mixing has been achieved. The Kolmogorov-Smirnov test is a non-parametric test for chain mixing and indicates whether chain values are similar across each 100 iterations (for this test to pass, the $p$-value should be 0.05 or above; non-significant). Finally, regression results in Bayesian modelling are interpreted with higher propensity density and $95 \%$ credibility intervals, which are similar to $95 \% \mathrm{CI}$ and should not also cross zero (the classic $p$-value is therefore not provided).
TABLE 2: Unstandardised and standardised loadings for the latent factors at time interval 1 (T1).

\begin{tabular}{lcccccc}
\hline Factor & Item & $\begin{array}{c}\text { Unstd. } \\
\text { loading }\end{array}$ & $\begin{array}{c}\text { Std. } \\
\text { loading }\end{array}$ & SE & $p$ & Intercept \\
\hline Strengths use (T1) & SU1 & 1.00 & 0.79 & 0.03 & 0.001 & 3.69 \\
& SU2 & 1.03 & 0.82 & 0.02 & 0.001 & 3.54 \\
& SU3 & 1.13 & 0.86 & 0.02 & 0.001 & 3.67 \\
& SU4 & 1.18 & 0.87 & 0.02 & 0.001 & 3.37 \\
& SU5 & 1.17 & 0.87 & 0.02 & 0.001 & 3.26 \\
Deficit correction & DI1 & 1.00 & 0.83 & 0.03 & 0.001 & 3.14 \\
(T1) & DI2 & 1.08 & 0.90 & 0.02 & 0.001 & 3.24 \\
& DI3 & 1.00 & 0.79 & 0.03 & 0.001 & 3.10 \\
& DI4 & 1.01 & 0.82 & 0.03 & 0.001 & 3.18 \\
& DI5 & 0.76 & 0.69 & 0.04 & 0.001 & 3.68 \\
& DI6 & 0.89 & 0.75 & 0.03 & 0.001 & 3.00 \\
Work engagement & VIG1 & 1.00 & 0.74 & 0.04 & 0.001 & 4.22 \\
& VIG2 & 1.03 & 0.85 & 0.03 & 0.001 & 4.59 \\
& VIG3 & 1.25 & 0.85 & 0.03 & 0.001 & 4.51 \\
& DED2 & 1.14 & 0.91 & 0.02 & 0.001 & 4.86 \\
& DED3 & 1.24 & 0.88 & 0.03 & 0.001 & 4.61 \\
& DED4 & 0.94 & 0.83 & 0.03 & 0.001 & 5.26 \\
& ABS3 & 0.89 & 0.78 & 0.04 & 0.001 & 5.02 \\
& ABS4 & 0.95 & 0.80 & 0.04 & 0.001 & 4.87 \\
& ABS5 & 0.76 & 0.53 & 0.06 & 0.001 & 4.34 \\
\hline
\end{tabular}

$\mathrm{SE}$, standard error; Unstd. loading, unstandardised loading; Std. loading, standardised loading.

All $p$-values $<0.001$

\section{Results \\ Dropout analysis}

As latent variables could not be substantially created at the time 2, and that this was not a randomised control study which included an intervention, it was decided to conduct analysis on the time 1 variables. That is, whether the participants who completed at both times $(n=79)$ differed at time 1 with those who dropped out on their strengths use, deficit correction and work engagement as per Cohen's $d$ effect size. Results showed that there were no practically significant latent mean differences. Values were as follows: strengths use (M: 0.00, SD: $1.00[n=79], \mathrm{M}:-0.05, \mathrm{SD}: 1.00$ [ $n=297$ [ [Cohen's $d=0.05])$; deficit correction (M: 0.00, SD: 1.00 [ $n=79$ ], M: 0.01, SD: 1.00 [ $n=297]$ [Cohen's $d=0.01])$; and work engagement (M: 0.00, SD: $1.00[n=79]$, M: -0.19, SD: $1.00[n=297]$ [Cohen's $d=0.19])$. Analysis therefore continued.

\section{Time 1 data: Measurement model}

The results from the CFA revealed that the specified measurement model fits the data well. This is indicated by the fit indices as follows: CFI (0.94), TLI (0.93), RMSEA (0.06) and SRMR (0.04). The factors measured by the SUDCO were POS for strength use and POS for deficit improvement.

In Table 2, the factor loadings of the measurement model are presented. All of the items loaded significantly onto their respective factors (estimate $>0.60$ ). However, item ABS5 (an absorption item) indicated a lower but acceptable loading of 0.53. The unstandardised loadings and intercepts are also presented, as they were used to inform the longitudinal model in the next section of the results. 
The correlations from the SUDCO dimensions and work engagement to determine the relationship between the variables are presented in Table 3.

Correlations revealed that POS for strengths use and POS for deficit correction are practically and significantly correlated to each other with a large effect $(r=0.83)$. Strengths use was also correlated to work engagement to a large degree $(r=0.62)$. Similarly, deficit correction was practically and significantly correlated to work engagement with a large effect $(r=0.53)$. All relationships were in a positive direction.

\section{Time 2 data: Longitudinal evidence}

\section{Factor scores model}

The results of the model to obtain factor scores for the factors at time 1 and time 2 were an adequate fit to the data. Specifically, the following fit indices were shown: CFI (0.91),
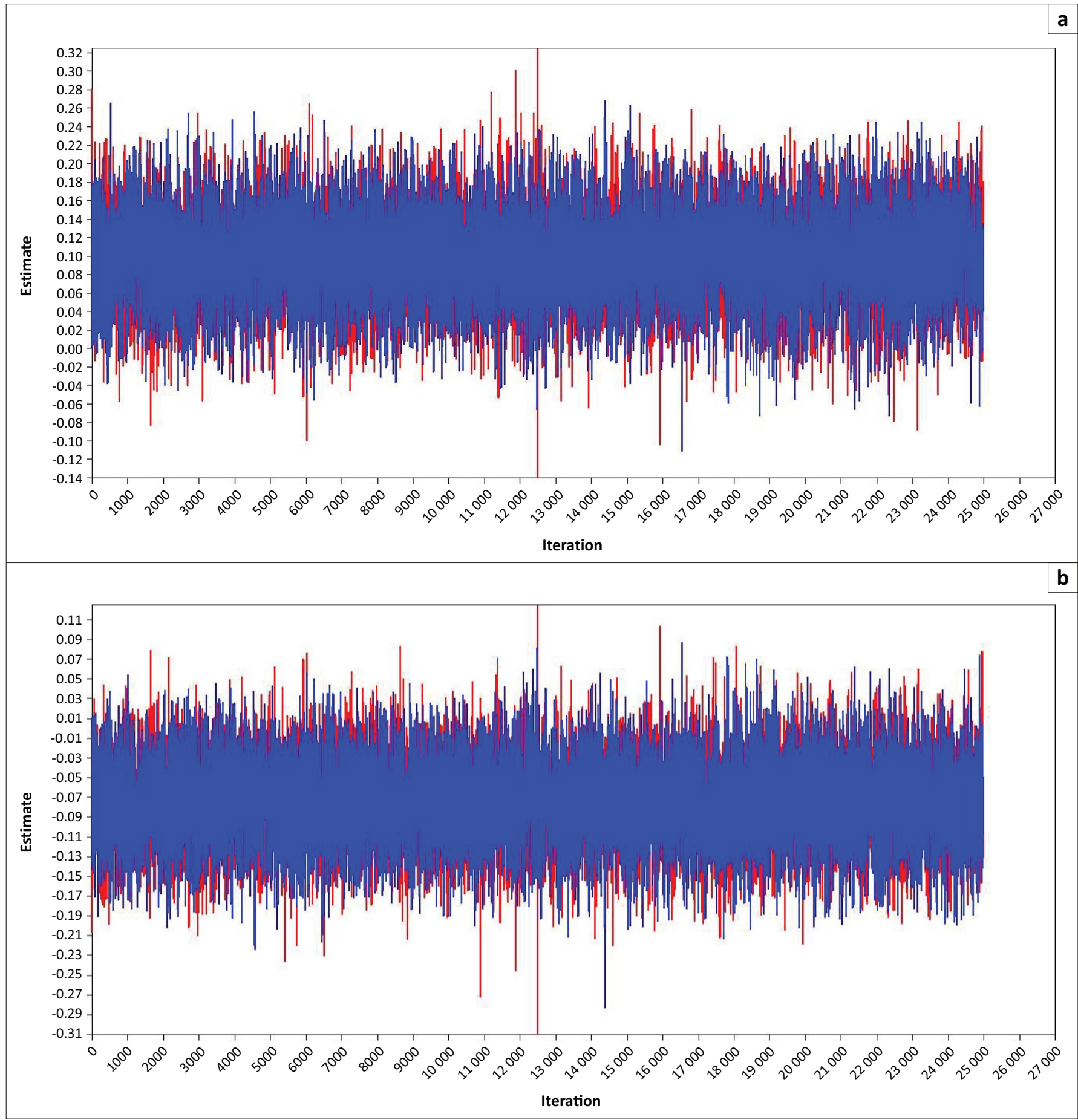

See Table 4 for results with $95 \%$ confidence interval.

FIGURE 1: Plots for chain convergence and parameter distributions. Parameters: (a) Perceived organisational support for deficit correction (T1) predicting engagement (T2) and (b) perceived organisational support for strengths use (T1) predicting engagement (T2). Kernel density plots: (c) Perceived organisational support for deficit correction (T1) predicting engagement (T2) and (d) perceived organisational support for strengths use (T1) predicting engagement (T2). 


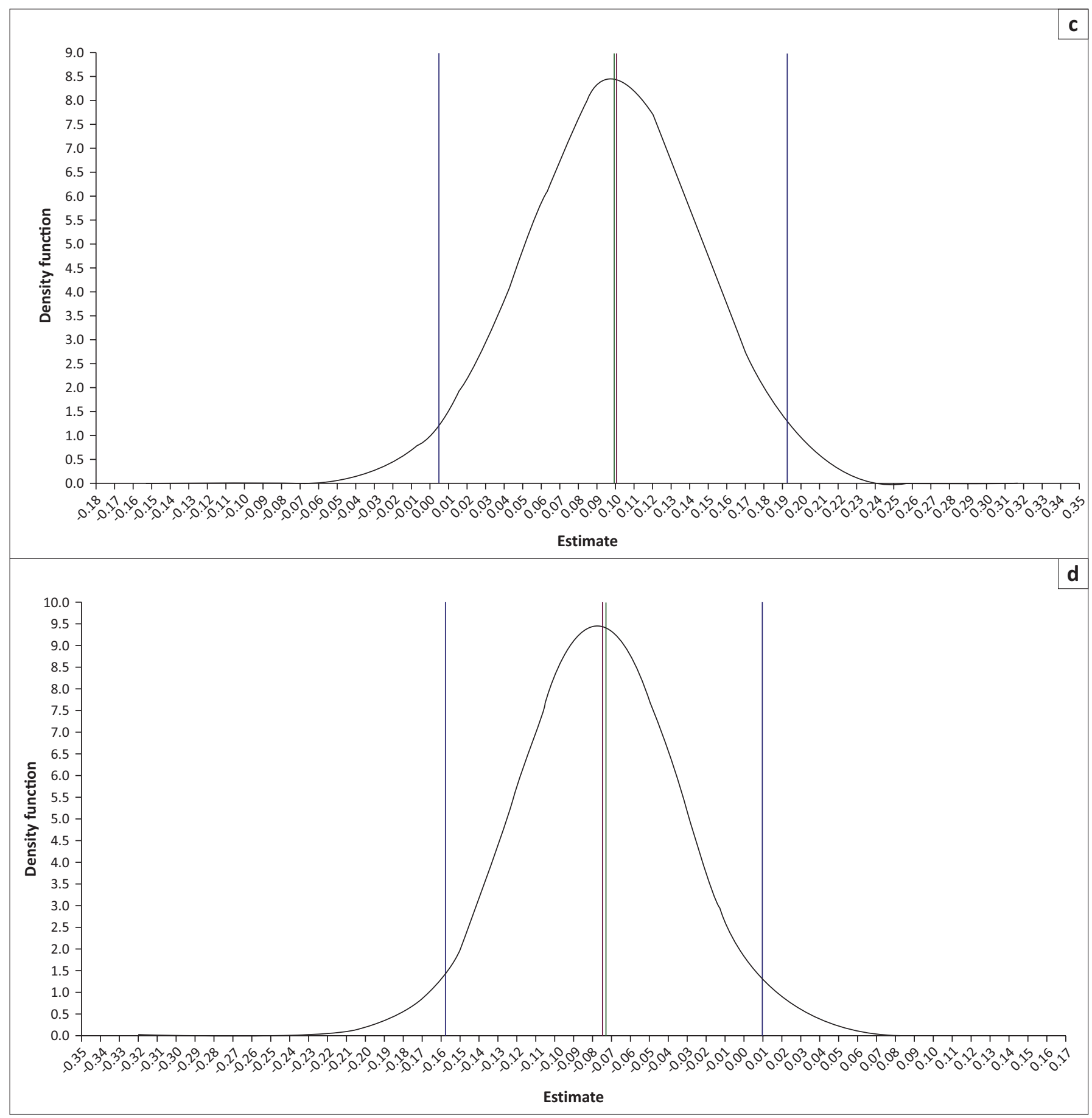

See Table 4 for results with $95 \%$ confidence interval.

FIGURE 1 (Continues...): Plots for chain convergence and parameter distributions. Parameters: (a) Perceived organisational support for deficit correction (T1) predicting engagement (T2) and (b) perceived organisational support for strengths use (T1) predicting engagement (T2). Kernel density plots: (c) Perceived organisational support for deficit correction (T1) predicting engagement (T2) and (d) perceived organisational support for strengths use (T1) predicting engagement (T2).

TLI (0.90), RMSEA (0.06) and SRMR (0.08). Based on the factor scores, the analysis continued with Bayesian estimation.

\section{Convergence and chain mixing}

After 25000 iterations, the model was below a PSR value of 1.05. The Kolmogorov-Smirnov test also showed that there were no significant differences on any of the parameters between the chains, indicating convergence of the model with adequate mixing. Figure 1 presents visual evidence of the parameter trace plots and distribution for the relationships of interest. As can be seen, sufficient chain mixing took place between the two chains by mixing adequately, and the distribution of the presented parameters is normal (smoothed). Given this evidence, interpretation of the results continued.

\section{Factor loadings and correlations}

The factor loadings for the model in the second test are indicated in Table 4. 
TABLE 3: Correlation matrix for the latent variables.

\begin{tabular}{lccc}
\hline Variables & $\mathbf{1}$ & $\mathbf{2}$ & $\mathbf{3}$ \\
\hline 1. Strengths use (T1) & $(1)$ & - & - \\
2. Deficit correction (T1) & 0.83 & $(1)$ & - \\
3. Work engagement (T1) & 0.62 & 0.53 & (1) \\
\hline
\end{tabular}

All correlations are statistically significant at $p<0.001$

TABLE 4: Standardised loadings for the latent factors at time interval 2 (T2).

\begin{tabular}{|c|c|c|c|c|c|}
\hline Factor & Item & Estimate & SD & Lower $95 \% \mathrm{Cl}$ & Upper $95 \% \mathrm{Cl}$ \\
\hline \multirow[t]{5}{*}{ Strengths use (T1) } & SU1 & 0.79 & 0.02 & 0.74 & 0.82 \\
\hline & SU2 & 0.82 & 0.02 & 0.78 & 0.86 \\
\hline & SU3 & 0.86 & 0.02 & 0.82 & 0.89 \\
\hline & SU4 & 0.87 & 0.02 & 0.83 & 0.90 \\
\hline & SU5 & 0.87 & 0.02 & 0.84 & 0.89 \\
\hline \multirow{6}{*}{$\begin{array}{l}\text { Deficit correction } \\
\text { (T1) }\end{array}$} & DI1 & 0.84 & 0.02 & 0.80 & 0.87 \\
\hline & $\mathrm{DI} 2$ & 0.90 & 0.01 & 0.87 & 0.92 \\
\hline & DI3 & 0.79 & 0.02 & 0.75 & 0.83 \\
\hline & DI4 & 0.82 & 0.02 & 0.77 & 0.85 \\
\hline & DI5 & 0.67 & 0.03 & 0.61 & 0.73 \\
\hline & DI6 & 0.75 & 0.03 & 0.70 & 0.80 \\
\hline \multirow[t]{5}{*}{ Strengths use (T2) } & SU1 & 0.77 & 0.04 & 0.70 & 0.84 \\
\hline & SU2 & 0.82 & 0.04 & 0.73 & 0.87 \\
\hline & SU3 & 0.82 & 0.04 & 0.74 & 0.87 \\
\hline & SU4 & 0.81 & 0.04 & 0.74 & 0.88 \\
\hline & SU5 & 0.83 & 0.04 & 0.75 & 0.89 \\
\hline \multirow{4}{*}{$\begin{array}{l}\text { Deficit correction } \\
\text { (T2) }\end{array}$} & DI1 & 0.90 & 0.03 & 0.84 & 0.94 \\
\hline & $\mathrm{DI} 2$ & 0.90 & 0.02 & 0.86 & 0.94 \\
\hline & DI3 & 0.82 & 0.04 & 0.74 & 0.88 \\
\hline & DI4 & 0.84 & 0.04 & 0.75 & 0.89 \\
\hline \multirow{2}{*}{$\begin{array}{l}\text { Deficit correction } \\
\text { (T2) }\end{array}$} & DI5 & 0.69 & 0.04 & 0.60 & 0.77 \\
\hline & DI6 & 0.80 & 0.04 & 0.72 & 0.86 \\
\hline \multirow{9}{*}{$\begin{array}{l}\text { Work engagement } \\
\text { (T1) }\end{array}$} & VIG1 & 0.75 & 0.03 & 0.70 & 0.79 \\
\hline & VIG2 & 0.85 & 0.02 & 0.81 & 0.88 \\
\hline & VIG3 & 0.85 & 0.02 & 0.82 & 0.88 \\
\hline & DED2 & 0.91 & 0.01 & 0.89 & 0.93 \\
\hline & DED3 & 0.89 & 0.01 & 0.85 & 0.91 \\
\hline & DED4 & 0.84 & 0.02 & 0.80 & 0.87 \\
\hline & ABS3 & 0.78 & 0.02 & 0.73 & 0.83 \\
\hline & ABS4 & 0.80 & 0.02 & 0.75 & 0.84 \\
\hline & ABS5 & 0.54 & 0.04 & 0.45 & 0.62 \\
\hline \multirow{9}{*}{$\begin{array}{l}\text { Work engagement } \\
\text { (T2) }\end{array}$} & VIG1 & 0.88 & 0.03 & 0.81 & 0.92 \\
\hline & VIG2 & 0.86 & 0.03 & 0.80 & 0.91 \\
\hline & VIG3 & 0.93 & 0.02 & 0.88 & 0.96 \\
\hline & DED2 & 0.95 & 0.02 & 0.91 & 0.97 \\
\hline & DED3 & 0.89 & 0.03 & 0.83 & 0.93 \\
\hline & DED4 & 0.83 & 0.03 & 0.76 & 0.89 \\
\hline & ABS3 & 0.85 & 0.03 & 0.77 & 0.91 \\
\hline & ABS4 & 0.86 & 0.03 & 0.79 & 0.91 \\
\hline & ABS5 & 0.78 & 0.05 & 0.67 & 0.85 \\
\hline
\end{tabular}

SD, posterior standard deviation; all values were acceptable, that is, did not cross zero.

As can be seen, all of the items had acceptable positive factor loadings on their respective factors, that is, all the loadings were above 0.50 . The standard errors (SEs) for the loadings were also relatively small, indicating the accuracy of the estimation of the loadings.

As shown in Table 5, the results revealed that POS for strengths use and POS for deficit correction are practically and significantly correlated to each other to a large effect $(r=0.83$; large effect). Similarly, strengths use and deficit improvement are positively correlated to work engagement to a large degree $(r=0.61$; large effect), respectively.
TABLE 5: Correlation matrix for the latent variables at time 2.

\begin{tabular}{lcccccc}
\hline Variables & $\mathbf{1}$ & $\mathbf{2}$ & $\mathbf{3}$ & $\mathbf{4}$ & $\mathbf{5}$ & $\mathbf{6}$ \\
\hline 1. POS for strengths use (T2) & 1.00 & - & - & - & - & - \\
2. POS for deficit correction (T2) & 0.83 & 1.00 & - & - & - & - \\
3. Work engagement (T2) & 0.61 & 0.61 & 1.00 & - & - & - \\
4. POS for strengths use (T1) & 0.96 & 0.84 & 0.63 & 1.00 & - & - \\
5. POS for deficit correction (T1) & 0.84 & 0.95 & 0.56 & 0.84 & 1.00 & - \\
6. Work engagement (T1) & 0.61 & 0.55 & 0.94 & 0.66 & 0.56 & 1.00 \\
\hline All correlations are statistically significant at $p<0.001$. & & & & \\
POS, perceived organisational support.
\end{tabular}

TABLE 6: Regression analysis.

\begin{tabular}{|c|c|c|c|c|c|}
\hline Structural path & Estimate & $\begin{array}{l}\text { Posterior } \\
\text { SD }\end{array}$ & $\begin{array}{l}\text { Lower } \\
95 \% \mathrm{Cl}\end{array}$ & $\begin{array}{l}\text { Upper } \\
95 \% \mathrm{Cl}\end{array}$ & Sig. \\
\hline $\begin{array}{l}\text { Eng (T1) } \rightarrow \text { POS for strengths } \\
\text { use (T2) }\end{array}$ & 0.13 & 0.03 & 0.08 & 0.18 & $*$ \\
\hline $\begin{array}{l}\text { POS for strengths use }(\mathrm{T} 1) \rightarrow \text { POS } \\
\text { for strengths use }(\mathrm{T} 2)\end{array}$ & 0.87 & 0.02 & 0.84 & 0.90 & $*$ \\
\hline $\begin{array}{l}\text { Eng (T1) } \rightarrow \text { POS for deficit } \\
\text { correction (T2) }\end{array}$ & 0.02 & 0.03 & -0.03 & 0.07 & - \\
\hline $\begin{array}{l}\text { POS for deficit correction (T1) } \rightarrow \\
\text { POS for deficit correction (T2) }\end{array}$ & 0.94 & 0.01 & 0.90 & 0.96 & $*$ \\
\hline Eng (T1) $\rightarrow$ Eng (T2) & 0.94 & 0.02 & 0.89 & 0.98 & $*$ \\
\hline $\begin{array}{l}\text { POS for strengths use (T1) } \rightarrow \text { Eng } \\
\text { (T2) }\end{array}$ & -0.08 & 0.04 & -0.16 & 0.01 & - \\
\hline $\begin{array}{l}\text { POS for deficit correction (T1) } \rightarrow \\
\text { Eng (T2) }\end{array}$ & 0.10 & 0.05 & 0.01 & 0.19 & $*$ \\
\hline
\end{tabular}

POS, perceived organisational support; SD, standard deviation; Cl, confidence interval; sig*., statistical significance.

\section{Regressions}

Table 6 presents the regression results.

Table 6 provides the structural paths between work engagement at time 1 and POS for strengths use at time 2 $(\beta=0.13 ; \mathrm{SE}=0.03 ; 95 \% \mathrm{CI}[0.08,0.18])$. It also provides insight into the relationship between POS for strengths use at time 1 and POS for strengths use at time $2(\beta=0.87 ; \mathrm{SE}=0.02$; $95 \%$ CI $[0.84,0.90])$. The regression analysis indicates that work engagement at time 1 and POS for strengths use at time 1 are predictors of POS for strengths use at time 2 . Both of the structural regressions did not cross zero in the $95 \%$ confidence interval, indicating a trustworthy estimate value.

Also, the structural paths between work engagement at time 1 and POS for deficit correction at time 2 ( $\beta=0.02 ; \mathrm{SE}=0.03$; $95 \%$ CI $[-0.03,0.07])$ are presented. It also provides insight into the relationship between POS for deficit correction at time 1 and POS for deficit correction at time $2(\beta=0.94$; $\mathrm{SE}=0.01 ; 95 \% \mathrm{CI}[0.91,0.96])$. The regression analysis indicates that work engagement at time 1 is not a significant predictor of POS for deficit correction at time 2, as the $95 \%$ credibility interval for the estimate went through zero. However, the analysis confirmed that POS for deficit correction at time 1 was a significant predictor of POS for deficit correction at time 2 .

The regression analysis further revealed that work engagement at time 1 is a predictor of work engagement at time 2 ( $\beta=0.94 ; \mathrm{SE}=0.02 ; 95 \% \mathrm{CI}[0.89,0.98])$. By the same token, POS for deficit correction at time 1 was a significant predictor of work engagement at time $2(\beta=0.10$; $\mathrm{SE}=0.05$; $95 \%$ CI $[0.01,0.19])$. However, POS for strengths use at time 1 
did not predict work engagement at time 2 as the estimate crossed zero $(\beta=-0.08 ; \mathrm{SE}=0.04 ; 95 \% \mathrm{CI}[-0.16,0.01])$.

\section{Ethical considerations}

Consent from the mining organisation's management was sought and approved. A letter explaining the objective of the study and motivation was provided. Participation in the study was voluntary and the confidentiality of participants was emphasised.

As this was a research study, ethical considerations were taken into account. Reinforcing voluntary participation, informed consent, doing no harm and confidentiality were of primary importance to this study.

\section{Discussion}

This study sought to answer whether POS for strengths use and POS for deficit correction were significant predictors of work engagement over time. The study aimed at addressing the gap in the literature, as previous research on these constructs has been conducted from a cross-sectional perspective. A sample within the South African mining industry was surveyed in two waves which were 3 months apart.

The results revealed that both POS for strengths use and POS for deficit correction are positively related to work engagement. This supports and confirms hypotheses 1a and $1 b$, stating that a positive relationship exists between job resources (POS for strengths use and POS for deficit correction) and work engagement. This finding is in line with various studies that have confirmed a positive relationship between these constructs (Botha \& Mostert, 2014; Harter et al., 2002; Linley \& Harrington, 2006; Salas et al., 2012; Stander et al., 2014). The findings can further be substantiated by making reference to the JD-R model, where job resources were found to be the main predictors of work engagement. From an organisational perspective, it has been proven that POS for strengths use is another form of job resources. This is because of its inherent nature of providing an environment where employees can use their strengths, which in turn may result in them using their abilities and dedicating efforts to achieve tasks at work (Demerouti \& Bakker, 2011; Van Woerkom et al., 2016). Similarly, POS for deficit correction is conceptualised as a job resource, because it can minimise or eliminate behaviour and/or skills that do not contribute to the attainment of business goals (Smits et al., 2012). In addition, HR practices in support of improving deficits develop employees as well as foster their growth. Schaufeli and Taris (2013) believe that work engagement is likely to be achieved when an employee continually invests physical and/or emotional effort to reach work objectives within the context of supportive organisational resources. Because POS for strengths use and POS for deficit correction have been conceptualised as such, it was expected that they will be positively related to work engagement.
The second hypothesis stated that POS for strengths use is a significant predictor of work engagement over time. Unexpectedly, the results established that POS for strengths use was not a significant predictor of work engagement over time; therefore, Hypothesis 2a was rejected. This finding is in contrast with longitudinal research conducted by Wood, Linley, Maltby, Kashdan and Hurling (2011), where the authors established that employees who utilised their strengths in work activities recorded higher levels of work engagement over time. Referencing the JD-R model, other studies also recorded significant positive longitudinal relationships between job resources and work engagement (Llorens et al., 2007; Mauno et al., 2007). As mentioned previously, the stability of work engagement could have played a role in the non-significant relations; however, studies with shorter follow-up time frames have recorded work engagement levels fluctuating (Bakker \& Bal, 2010; Sonnentag, 2003; Sonnentag, Dormann \& Demerouti, 2010), thereby nullifying the stability argument.

On the contrary, in a study conducted by Smits et al. (2012), the authors established in their preliminary analysis that the predictive power of strengths use on work engagement largely disappeared when placed in the same model with deficit improvement behaviour. Although a stepwise regression analysis was not adopted in this study, the findings by Smits et al. (2012) could potentially explain the reason for POS for strengths use not significantly predicting work engagement in time 2. Another explanation for the unexpected results can be obtained by understanding the organisational climate of the surveyed company. The mining industry and the population surveyed are made up of subject matter experts, who are professionals in their fields. Furthermore, the highly technological aspects of the industry require employees to stay abreast by remaining innovative and constantly coming up with new ways of mining faster and cheaper, yet maintaining safety standards. This expectation requires employees to dig deep within their professional expertise and to bridge the gap between the knowledge they currently have and what is required for future success. The surveyed organisation places a great deal of emphasis on the expert knowledge of their employees. Given the many challenges that the industry as a whole is facing, it requires the best talent to ensure sustainability and survival. It is probable that the levels of work engagement were not significantly altered, as the psychological climate within the organisation is such that employees equate building on their weaknesses as potential for future success, and therefore not showing strong levels of engagement when utilising their strengths.

In contrast, Hypothesis $2 \mathrm{~b}$ (which stated that POS for deficit correction is a significant predictor of work engagement over time) was confirmed. This is congruent with longitudinal studies (previously mentioned) that purport that job resources predict work engagement over time. Practically, given that the employees are already in a climate that highly esteems a strength-based focus, it could be argued that employees feel that an organisation that 
supports them in improving their weaknesses can help in the quest to achieve even better business goals, thereby possibly influencing a strong sense of work engagement. In studies conducted by Els et al. (2015) and Van Niekerk et al. (2016), deficit correction behaviour was found to predict higher levels of work engagement compared to strengths use behaviour. This has been attributed to individuals feeling valued and supported in rectifying their weaknesses. In addition, employees may feel challenged, fulfilled and may feel a sense of accomplishment when improving their weaknesses, thereby responding with motivation and commitment, leading to higher levels of engagement (Els et al., 2015; Tannenbaum, Mathieu, Salas \& Cannon-Bowers, 1991; Van Niekerk et al., 2016).

The results further explained the relationship between the job resources (POS for strengths use and POS for deficit correction) and work engagement by observing the reversed causal relationship, which means looking at how work engagement at time 1 influences job resources at time 2 . In the case of POS for strengths use, it was found that work engagement at time 1 indeed predicts POS for strengths use at time 2. This finding is in line with Llorens et al.'s (2007) study, where the normal, reciprocal and reversed influences of work engagement were investigated. It was found that work engagement at time 1 had a significant impact on job resources at time 2. This phenomenon was explained by De Beer, Pienaar and Rothmann (2013) who made reference to the motivational process of the JD-R model and introduced the concept of a 'perceptual hypothesis'. The authors reason that each individual has a perception of his or her job conditions, and that those conditions can change because of an increase in commitment or strain. Having said that, committed employees could view their working conditions more favourably because of the presence of job resources (De Beer et al., 2013), which explains the reason in this study where work engagement (committed employees) at time 1 predicts POS for strengths use at time 2.

Unexpectedly in this study, the reversed effect of work engagement on POS for deficit correction at time 2 was not significant. This finding illustrates an opposite effect to what previous studies have found regarding the reversed causal effects of work engagement on job resources (Bakker \& Bal, 2010). However, the non-significance is to a small degree, and this finding could be sample specific.

Lastly, the relationship between job resources at time 1 and job resources at time 2 was significant. This practically means that POS for SUDCO at time 1 predicts POS for SUDCO at time 2. This finding can be explained by referencing the conservation of resources theory (Hobfoll, 2001), which states that individuals will try to maintain and foster resources that are valuable and important to them in attaining future goals (Salanova, Schaufeli, Xanthopoulou \& Bakker, 2010). Furthermore, this theory makes assumptions about 'loss spirals' and 'gain spirals' where resources may either diminish or increase (Hobfoll, 2001). The latter, which helps explain the findings in this study, elaborates that the gaining of (job) resources has the potential to increase more resources, making it more likely to seek and acquire additional (job) resources (Llorens et al., 2007). Simply stated, it is probable for employees to acquire and seek more job resources in the future, once they are in the possession of current job resources.

\section{Practical implications}

The aim of the study was to determine the longitudinal relationship between an organisational environment that supports the use of strengths as well as the correction of weaknesses and how those affect work engagement. Given the South African landscape and the emphasis on the training and development of employees, it is important for organisations to understand which approach has the best long-term benefits on the bottom line. Through this study, it has been determined that an environment that supports the correction of deficits influences employees' levels of work engagement in the longer term. Given this, it is therefore justified for organisations to invest money (long term) in development interventions, such as succession planning, as it has been established that work engagement has direct impact on organisational bottom lines (Bakker et al., 2011; George, 2010).

Furthermore, the results indicated that POS for strengths use is positively related to work engagement in the shorter term together with POS for deficit correction. It is therefore advisable for organisations to focus on both employee SUDCO when development in the short term is required. For example, development to assist an employee to excel in a current role could be addressed by utilising both a strengths use approach and a deficit correction approach. Furthermore, development interventions that are short term and time constrained, such as coaching, could also benefit from following both a strengths-based and a deficit correction approach.

From an employee perspective, it is important for employees to have the right tools to navigate this complex and changing world of work. Having the knowledge of how to better develop themselves may have a positive impact on employees' performance and career progression. It has been established that employees who are engaged have better inrole performance (Schaufeli et al., 2006) and that having the opportunity to address their weaknesses can lead to career advancement (Benson, 2006) and remaining relevant and marketable in their fields (Rothwell \& Arnold, 2007).

In terms of the field of industrial psychology, research on these forms of job resources and their relation to work engagement from a longitudinal perspective is lacking. This study aimed at addressing that gap by focusing it within the South African context.

\section{Limitations and recommendations}

In this study, valuable findings were concluded on the antecedents of work engagement within the South African 
mining industry over time. However, this research study is not without limitations. Firstly, a longitudinal approach was undertaken to explore causal relationships between the constructs. However, it has been recorded that both strengths use and work engagement are stable phenomena (Hakanen et al., 2011; Mauno et al., 2007; Schaufeli et al., 2009; Van Woerkom et al., 2015) and therefore utilising research designs with a shorter time frame, such as weekly diaries, could better explain variations and differences in the levels of the constructs (Bakker \& Bal, 2010; Fritz \& Sonnentag, 2007).

Secondly, the study has limitation with regard to the compilation of the sample. It consisted of individuals at various levels and departments within a single large organisation in the mining industry. The results therefore cannot be generalised to all organisations within the South African context and caution should be taken when making any generalisations. It is therefore recommended that a more diverse sample, such as a multi-industry group, be utilised for future research. In addition, the study made use of convenience sampling. The sample was taken from the South African mining industry, where the majority of respondents constituted white male population. Based on this homogeneous population, generalisations cannot be made, as the sample does not reflect the diversity, that is, the South African population. It is suggested that future research should make use of a probability sampling strategy to enhance the generalisability of the research results.

Thirdly, the sample size indicating the longitudinal evidence was very small. Generally, larger sample sizes increase the probability of obtaining significance because they reflect the population mean more reliably (Boyd, Briggs, Fenwick, Norrie \& Stock, 2011). Generalisations can therefore not be made with respect to the findings of this study. It is therefore suggested that future research should collect data from a larger sample size to overcome this limitation.

Lastly, the study utilised self-report questionnaires in the collection of data. Spector (1994) has criticised this approach as it increases measurement bias. Furthermore, when people respond to self-report questionnaires, there is a possibility of social desirability occurring. This simply means that respondents may present themselves in a positive image when responding to the questionnaire (Johnson \& Fendrich, 2005). In this study, the constructs being measured were of a subjective nature, thereby restricting the manner in which this problem could be addressed (Salkind, 2009).

\section{Conclusion}

In this study, it was found that employees who believe that an organisation that supports them to correct their deficits will experience higher levels of work engagement over time. Furthermore, the study established that in the short term, an environment that supports the use of strengths will yield higher levels of engagement. The long-term effect of POS for strengths use on employees' work engagement was not established in this study, but it is suggested that future research should further investigate this causal relationship. The sample in this study included employees within the mining industry of South Africa. This study provides much needed clarity on the debate as to which approach (strengthsbased or deficit correction approach) has a positive impact on work engagement over time. It is therefore recommended that organisations should invest in development interventions which help their employees correct their weaknesses for long-term benefits, and that an environment that supports the use for strengths is beneficial in the short term.

\section{Acknowledgements Competing interests}

The authors declare that they have no financial or personal relationships that may have inappropriately influenced them in writing this article.

\section{Authors' contributions}

P.M. fulfilled the role of the primary researcher, and this study formed part of her masters' research. She was responsible for the conceptualisation of the article, collecting of the data, interpretation of the research results and the writing of the article. C.E., L.T.d.B. and K.M. acted as supervisor, co-supervisor and assistant supervisor, respectively. These authors played an advisory role in this study and assisted in the conceptualisation of the study, interpretation of the research results and the writing of the research article. L.T.d.B. also conducted the statistical analyses.

\section{References}

Abdullah, Z., Ahsan, N., \& Alam, S.S. (2009). The effect of human resource management practices on business performance among private companies in Malaysia. International Journal of Business and Management, 4(6), 65-72. https://doi. org/10.5539/ijbm.v4n6p65

Anguinis, H., \& Kraiger, K. (2009). Benefits of training and development for individuals and teams, organizations and society. Annual Review of Psychology, 60, 451-474. https://doi.org/10.1146/annurev.psych.60.110707.163505

Aquino, K., \& Griffeth, R.W. (1999). An exploration of the antecedents and consequences of perceived organizational support: A longitudinal study. Unpublished manuscript. University of Delaware and Georgia State University.

Arthur, W., Jr., Bennett, W., Jr., Edens, P.S., \& Bell, S.T. (2003). Effectiveness of training in organizations: A meta-analysis of design and evaluation features. Journal of Applied Psychology, 88(2), 234-245. https://doi.org/10.1037/0021-9010.88.2.234

Bakker, A.B., Albrecht, S.L., \& Leiter, M.P. (2011). Work engagement: Further Psychology, 20(1), 74-88. https://doi.org/10.1080/1359432X.2010.546711

Bakker, A.B., \& Bal, M. (2010). Weekly work engagement and performance: A study among starting teachers. Journal of Occupational and Organizational Psychology, 83(1), 189-206. https://doi.org/10.1348/096317909X402596

Bakker, A.B., \& Demerouti, E. (2007). The Job Demands-Resources model: State of the art. Journal of Managerial Psychology, 22(3), 309-328. https://doi.org/ $10.1108 / 02683940710733115$

Bakker, A.B., Demerouti, E., \& Euwema, M.C. (2005). Job resources buffer the impact of job demands on burnout. Journal of Occupational Health Psychology, 10(2), 170-180. https://doi.org/10.1037/1076-8998.10.2.170

Bakker, A.B., Demerouti, E., Taris, T., Schaufeli, W.B., \& Schreurs, P. (2003). A multigroup analysis of the job demands-resources model in four home-care organizations. International Journal of Stress Management, 10(1), 16-38. https:// doi.org/10.1037/1072-5245.10.1.16

Bakker, A.B., \& Geurts, S. (2004). Toward a dual-process model of work-home interference. Work \& Occupations, 31(3), 345-366. https://doi.org/10.1177/ 0730888404266349

Bakker, A.B., Hakanen, J.J., Demerouti, E., \& Xanthopoulou, D. (2007). Job resources boost work engagement particularly when job demands are high. Journal of Educational Psychology, 99(2), 274-284. https://doi.org/10.1037/0022-0663. 99.2.274 
Bakker, A.B., Schaufeli, W.B., Leiter, M.P., \& Taris, T.W. (2008). Work engagement: An emerging concept in occupational health psychology. Work \& Stress, 22(3), 187200. https://doi.org/10.1080/02678370802393649

Barney, J. (1991). Firm resources and sustained competitive advantage. Journal of Management, 17(1), 99-120. https://doi.org/10.1177/014920639101700108

Barney, J. (2002). Gaining sustainable competitive advantage. Upper Saddle River, NJ: Prentice Hall.

Bartlett, K.R. (2001). The relationship between training and organizational commitment: A study in the health care field. Human Resource Developmen Quarterly, 12(4), 335-352. https://doi.org/10.1002/hrdq.1001

Bassi, L., Ludwig, J., McMurrer, D., \& Van Buren, M. (2000). Profiting from learning: Do firms' investments in education and training pay off? Alexandria, VA: American Society for Training and Development.

Benson, G.S. (2006). Employee development, commitment and intention to turnover: A test of 'employability' policies in action. Human Resource Management Journal, 16(2), 173-192. https://doi.org/10.1111/j.1748-8583.2006.00011.x

Biswas-Diener, R. (2010). Practicing positive psychology coaching: Assessment and strategies for success. Hoboken, NJ: Wiley.

Biswas-Diener, R., Kashdan, T.B., \& Minhas, G. (2011). A dynamic approach to psychological strength development and intervention. Journal of Positive Psychology, 6(2), 106-118. https://doi.org/10.1080/17439760.2010.545429

Blau, P.M. (1964). Justice in social exchange. Sociological Enquiry, 34(2), 193-206. https://doi.org/10.1111/j.1475-682X.1964.tb00583.x

Botha, C., \& Mostert, K. (2014). A structural model of job resources, organisational and individual strengths use and work engagement. SA Journal of Industrial Psychology/SA Tydskrif vir Bedryfsielkunde, 40(1), 1-11. https://doi.org/10.4102/ sajip. v40i1.1135

Boyd, K.A., Briggs, A.H., Fenwick, E., Norrie, J., \& Stock, S. (2011). Power and sample size for cost-effectiveness analysis. Contemporary Clinical Trials, 32(6), 893-901. https://doi.org/10.1016/j.cct.2011.07.007

Brown, T.A. (2015). Confirmatory factor analysis for applied research (2nd ed.). New York: Guilford Press.

Buckingham, M. (2007). Go put your strengths to work. New York: The Free Press.

Buckingham, M., \& Clifton, D.O. (2001). Now, discover your strengths. New York: The Free Press.

Christian, M.S., Garza, A.S., \& Slaughter, J.E. (2011). Work engagement: A quantitative review and test of its relations with task and contextual performance. Personnel Psychology, 64(1), 89-136. https://doi.org/10.1111/j.1744-6570.2010.01203.x

Clifton, D.O., \& Harter, J.K. (2003). Investing in strengths. In A.K.S. Cameron, B.J.E. Dutton, \& C.R.E. Quinn (Eds.), Positive organisational scholarship (pp. 111-121). San Francisco, CA: Berret-Koehler Publishers.

Cohen, J. (1988). Statistical power analysis for the behavioral sciences. Hillsdale, NJ: Lawrence Erlbaum Associates.

De Beer, L.T., Pienaar, J., \& Rothmann, S., Jr. (2013). Investigating the reversed causality of engagement and burnout in job demands-resources theory. SA Journal of Industrial Psychology/SA Tydskrif vir Bedryfsielkunde, 39(1), 1-9. https://doi. org/10.4102/sajip.v39i1.1055

De Braine, R., \& Roodt, G. (2011). The Job Demands-Resources model as predictor of work identity and work engagement: A comparative analysis. SA Journal of Industrial Psychology/SA Tydskrif vir Bedryfsielkunde, 37(2), 1-11. https://doi. org/10.4102/sajip.v37i2.889

De Bruin, G.P., \& Henn, C.M. (2013). Dimensionality of the 9-item Utrecht work engagement scale (UWES-9). Psychological Reports, 112(3), 788-799. https://doi. org/10.2466/01.03.PRO.112.3.788-799

Deci, W.L., \& Ryan, R.M. (1985). Intrinsic motivation and self-determination in human behavior. New York: Plenum.

Deficit, n. (2017). Oxford English dictionary. Retrieved October 31, 2016, from https:// en.oxforddictionaries.com/definition/deficit

De Lange, A.H., De Witte, H., \& Notelaers, G. (2008). Should I stay or should I go? Examining longitudinal relations among job resources and work engagement for stayers versus movers. Work \& Stress, 22(3), 201-223. https://doi. stayers versus movers. Work
org/10.1080/02678370802390132

Deloitte. (2016). Tracking the trends 2016: The top 10 issues mining companies will face in the coming year. Retrieved October 31,2016, from https://www2.deloitte. $\mathrm{com} /$ content/dam/Deloitte/global/Documents/Energy-and-Resources/gx-ertracking-the-trends-2016.pdf

Demerouti, E., \& Bakker, A.B. (2011). The job demands-resources model: Challenges for future research. SA Journal of Industrial Psychology/SA Tydskrif vir Bedryfsielkunde, 37(2), 1-9. https://doi.org/10.4102/sajip.v37i2.974

Demerouti, E., Bakker, A.B., De Jonge, J., Janssen, P.P.M., \& Schaufeli, W.B. (2001) Burnout and engagement at work as a function of demands and contro Scandinavian Journal of Work Environment and Health, 27(4), 279-286. https:// doi.org/10.5271/sjweh.615

Demerouti, E., Bakker, A.B., Nachreiner, F., \& Schaufeli, W.B. (2001). The Job DemandsResources model of burnout. Journal of Applied Psychology, 86(3), 499-512. https://doi.org/10.1037//0021-9010.86.3.499

De Pablos, P.O., \& Lytras, M.D. (2008). Competencies and human resource management: Implications for organizational competitive advantage. Journa of Knowledge Management, 12(6), 48-55. https://doi.org/org/10.1108/ 13673270810913612

Eisenberger, R., Armeli, S., Rexwinkel, B., Lynch, P.D., \& Rhoades, L. (2001) Reciprocation of perceived organizational support. Journal of Applied Psychology, 86(1), 42-51. https://doi.org/10.1037//0021-9010.86.1.42
Eisenberger, R., Huntington, R., Hutchison, S., \& Sowa, D. (1986). Perceived organizational support. Journal of Applied Psychology, 71(3), 500-507. https:// organizational support. Journal of Appl

Els, C., Mostert, K., \& Van Woerkom, M. (2015). Strengths use, deficit improvement or a focus on both for optimal organizational outcomes. Unpublished doctoral thesis, North-West University, South Africa. Retrieved October 31, 2016, from https:// dspace.nwu.ac.za/bitstream/handle/10394/15211/Els_C_2015.pdf

Fredrickson, B.L. (1998). What good are positive emotions? Review of Genera Psychology, 2(3), 300-319. https://doi.org/10.1037/1089-2680.2.3.300

Fredrickson, B.L. (2001). The role of positive emotions in positive psychology: The broaden-and-build theory of positive emotions. American Psychologist, 56(3), 218-226. https://doi.org/10.1037/0003-066X.56.3.218

Fredrickson, B.L. (2004). The broaden-and-build theory of positive emotions. The Royal Society, 359(1449), 1367-1377. https://doi.org/10.1098/rstb.2004.1512

Fritz, C., \& Sonnentag, S. (2007). Antecedents of day-level proactive behavior: A look at job stressors and positive affect during the workday. Journal of Management, 35(1), 94-111. https://doi.org/10.1177/0149206307308911

George, J.M. (2010). More engagement is not necessarily better: The benefits of fluctuating levels of engagement. In S.L. Albrecht (Ed.), Handbook of employee
engagement: Perspectives, issues, research and practice (pp. 253-263). engagement: Perspectives, issue
Cheltenham, UK: Edward Elgar.

Goaverts, N., Kyndt, E., Dochy, F., \& Baert, H. (2011). Influence of learning and working climate on the retention of talented employees. Journal of Workplace Learning, 23(1), 35-55. https://doi.org/10.1108/13665621111097245

González-Roma, V., Schaufeli, W.B., Bakker, A.B., \& Lloret, S. (2006). Burnout and work engagement: Independent factors or opposite poles? Journal of Vocational Behavior, 68(1), 165-174. https://doi.org/10.1016/j.jvb.2005.01.003

Gouldner, A.W. (1960). The norm of reciprocity: A preliminary statement. American Sociological Review, 25(2), 161-178. https://doi.org/10.2307/2092623

Hakanen, J.J., Bakker, A.B., \& Schaufeli, W. (2006). Burnout and engagement among teachers. Journal of School Psychology, 43(6), 495-513. https://doi.org/10.1016/j jsp.2005.11.001

Hakanen, J.J., Peeters, M.C.W., \& Perhoniemi, R. (2011). Enrichment processes and gain spirals at work and at home: A 3-year cross lagged panel study. Journal of Occupational and Organizational Psychology, 84(1), 8-30. https://doi. org/10.1111/j.2044-8325.2010.02014.x

Hakanen, J.J., Schaufeli, W.B., \& Ahola, K. (2008). The job demands resources model: A three-year cross-lagged study of burnout, depression, commitment, and work engagement. Work \& Stress, 22(1), 224-241. https://doi. org/10.1080/02678370802379432

Harter, J.K., Schmidt, F.L., \& Hayes, T.L. (2002). Business unit-level relationship between employee satisfaction, employee engagement, and business outcomes: org/10.1037//0021-9010.87.2.268

Harzer, C., \& Ruch, W. (2012). When the job is a calling: The role of applying one's signature strengths at work. The Journal of Positive Psychology, 7(5), 362-371. https://doi.org/10.1080/17439760.2012.702784

Harzer, C., \& Ruch, W. (2013). The application of signature character strengths and positive experiences at work. Journal of Happiness Studies, 14(3), 965-983. https://doi.org/10.1007/10902-012-9364-0

Hobfoll, S.E. (2001). The influence of culture, community, and the nested-self in the stress process: Advancing conservation resources theory. Applied Psychology: An International Review, 50(3), 337-370. https://doi.org/10.1111/1464-0597.00062

Jamasmie, C. (2015). About $10 \%$ of global gold output being produced at a loss. Retrieved October 31, 2016, from http://www.mining.com/about-10-percent-ofglobal-gold-output-being-produced-at-a-loss/

Jassim, R.K., \& Jaber, G. (1998). Competitive advantage through the employees. Research paper. Auckland, New Zealand: University of Auckland.

Johnson, T., \& Fendrich, M. (2005). Modeling sources of self-report bias in a survey of drug use epidemiology. Annals of Epidemiology, 15(5), 381-389. https://doi. org/10.1016/j.annepidem.2004.09.004

Keenan, E.M., \& Mostert, K. (2013). Perceived organisational support for strength use: The factorial validity and reliability of a new scale in the banking industry. SA use: The factorial validity and reliability of a new scale in the banking industry. SA
Journal of Industrial Psychology/SA Tydskrif vir Bedryfsielkunde, 39(1), 1-12. https://doi.org/10.4102/sajip.v39i1.1052

Keith, N., \& Frese, M. (2008). Effectiveness of error management training: A metaanalysis. Journal of Applied Psychology, 93(1), 59-69. https://doi. org/10.1037/0021-9010.93.1.59

Kosowski, R., Naik, N.Y., \& Teo, M. (2007). Do hedge funds deliver alpha? A Bayesian and bootstrap analysis. Journal of Financial Economics, 84(1), 229-264. https:// doi.org/10.1016/j.jfineco.2005.12.009

KPMG. (2016). Settling the dust in South African Mining: Mining risk survey. Retrieved October 31, 2016, from https://www.kpmg.com/ZA/en/industry/Mining/MiningExecutive-Forum/Documents/Mining\%20Risk\%20Survey\%20-\%20Settling\%20 the\%20Dust.pdf

Kretzmann, J.P., \& McKnight, J.L. (1993). Building communities from the inside out: A path toward finding and mobilizing a community's assets. Evaston, IL: Institute for Policy Research.

Lance, C.E., Butts, M.M., \& Michaels, L.C. (2006). The sources of four commonly reported cut-off criteria: What did they really say? Organizational Research Methods, 9(2), 202-220. https://doi.org/10.1177/1094428105284919

Langelaan, S., Bakker, A.B., Van Doornen, L.J.P., \& Schaufeli, W.B. (2006). Burnout and work engagement: Do individual differences make a difference? Personality and Individual Differences, 4O(3), 521-532. https://doi.org/10.1016/j.paid.2005.07.009 
Lee, C.H., \& Bruvold, N.T. (2003). Creating value for employees: Investment in employee development. The International Journal of Human Resource Management, 14(6), 981-1000. https://doi.org/10.1080/0958519032000106173

Linley, P.A., \& Harrington, S. (2006). Playing to your strengths. The Psychologist, 19(2), 86-89. https://doi.org/10.1080/17439760500372796

Linley, P.A., Joseph, S., Harrington, S., \& Wood, A.M. (2006). Positive psychology: Past, present and (possible) future. Journal of Positive Psychology, 1(1), 3-16. https:// doi.org/:10.1016/j.paid.2010.08.004

Llorens, S., Schaufeli, W.B., Bakker, A.B., \& Salanova, M. (2007). Does a positive gain spiral of resources, efficacy beliefs and engagement exist? Computers in Human Behavior, 23(1), 825-841. https://doi.org/10.1016/j.chb.2004.11.012

Macey, W.H., \& Scheider, B. (2008). The meaning of employee engagement. Journal of Industrial and Organizational Psychology, 1(1), 3-30. https://doi. org/10.1111/j.1754-9434.2007.0002.x

Mauno, S., Kinnunen, U., Mäkikangas, A., \& Feldt, T. (2010). Job demands and resources as antecedents of work engagement: A qualitative review and directions for future research. In S.L. Albrecht (Ed.), Handbook of employee engagement: Perspectives, issues, research and practice (pp. 111-128). Cheltenham, UK: Perspectives,

Mauno, S., Kinnunen, U., \& Ruokolainen, M. (2007). Job demands and resources as antecedents of work engagement: A longitudinal study. Journal of Vocational Behavior, 70(1), 149-171. https://doi.org/10.1016/j.jvb.2006.09.002

Menard, S.W. (2002). Longitudinal research (2nd ed.). Thousand Oaks, CA: Sage.

Metz, A.J., Burkhauser, M., \& Bowie, L. (2009). Training out-of-school time staff. Washington, DC: Child Trends.

Morris, M.A., \& Robie, C. (2001). A meta-analysis of the effects of cross-cultural training on expatriate performance and adjustment. International Journal of Training \& Development, 5(2), 112-125. https://doi.org/10.1111/1468 2419.00126

Mostert, K., Cronje, S., \& Pienaar, J. (2006). Job resources, work engagement and the mediating role of positive work-home interaction of police officers in the NorthWest province. Acta Criminologica, 19(3), 64-87. Retrieved October 31, 2016, from http://www.journals.co.za/crim/acta/index.html

Muthén, B. (2010). Bayesian analysis in Mplus: A brief introduction. Retrieved October 31, 2016, from http://www.statmodel.com/download/IntroBayesVersion3.pdf

Muthén, L.K., \& Muthén, B.O. (2015). Mplus user's guide (7th ed.). Los Angeles, CA: Muthén \& Muthén.

Noe, R.A. (2010). Employee training and development (5th ed.). New York: McGrawHill Irwin.

Olivier, A.L., \& Rothmann, S. (2007). Antecedents of work engagement in a multinational oil company. SA Journal of Industrial Psychology/SA Tydskrif vir Bedryfsielkunde, 33(3), 49-56. https://doi.org/10.4102/sajip.v33i3.396

Palo, J., \& Rothmann, S. (2016). Work engagement in the mining industry in South Africa: The role of tasks and relationships. Journal of Psychology in Africa, 26(3), 221-229. https://doi.org/10.1080/14330237.2016.1185901

Peterson, C., Stephens, J.P., Park, N., Lee, F., \& Seligman, M.E.P. (2009). Strengths of character and work. In P.A. Linley, S. Harrington, \& N. Garcia (Eds.), Oxford handbook of positive psychology and work (pp. 221-234). Oxford, UK: Oxford University Press.

Pfeffer, J., \& Sutton, R.I. (2006). Evidence-based management. Harvard Business Review, 84(1), 62-74.

PwC. (2014). Highlighting trends in the South African mining industry (6th ed.). SA Mine. Retrieved October 31, 2016, from https://www.pwc.co.za/en/assets/pdf/ sa-mine-2014-6th-edition-21-nov.pd

Rhoades, L., \& Eisenberger, R. (2002). Perceived organizational support: A review of the literature. Journal of Applied Psychology, 87(4), 698-714. https://doi. org/10.1037//0021-9010.87.4.698

Rich, B.L., LePine, J.A., \& Crawford, E.A. (2010). Job engagement: Antecedents and effects on job performance. Academy of Management Journal, 53(3), 617-635. https://doi.org/10.5465/AMJ.2010.51468988

Rothmann, S., \& Jordaan, G.M.E. (2006). Job demands, job resources and work engagement of academic staff in Southern African higher education institutions.
SA Journal of Industrial Psychology/SA Tydskrif vir Bedryfsielkunde, 32(4), 87-96. SA Journal of Industrial Psychology/SA
https://doi.org/10.4102/sajip.v32i4.247

Rothmann, S., \& Joubert, J.H.M. (2007). Job demands, job resources, burnout and work engagement of managers at a platinum mine in the North West Province. SA Journal of Business Management, 38(3), 49-61.

Rothwell, A., \& Arnold, J. (2007). Self-perceived employability: Development and validation of a scale. Personnel Review, 36(1), 23-41. https://doi. org/10.1108/00483480710716704

Rust, T., Diessner, R., \& Reade, L. (2009). Strengths only or relative weaknesses? A preliminary study. The Journal of Psychology, 143(5), 465-476. https://doi org/10.3200/JRL.143.5.465-476

Saks, A.M. (2006). Antecedents and consequences of employee engagement. Journal of Managerial Psychology, 21(7), 600-619. https://doi.org/10.1108/ 02683940610690169

Salanova, M., Agut, S., \& Peiró, J.M. (2005). Linking organizational resources and work engagement to employee performance and customer loyalty: The mediation of service climate. Journal of Applied Psychology, 90(6), 1217-1227. https://doi. org/10.1037/0021-9010.90.6.1217

Salanova, M., Schaufeli, W.B., Xanthopoulou, D., \& Bakker, A.B. (2010). The gain spiral of resources and work engagement. In A.B. Bakker \& M.P. Leiter (Eds.), Work engagement: $A$ handbook of essential theory and research (pp. 118-131). New York: Psychology Press.
Salas, E., Tannenbaum, S.I., Kraiger, K., \& Smith-Jentsch, K.A. (2012). The science of training and development in organizations: What matters in practice. Psychological
Science in the Public Interest, 13(2), 74-101. https://doi. Science in the Public
org/10.1177/1529100612436661

Salkind, N.J. (2009). Exploring research (7th ed.). Upper Saddle River, NJ: Pearson.

Schaufeli, W.B., \& Bakker, A.B. (2004). Job demands, job resources, and their relationship with burnout and engagement: A multi-study sample. Journal of Organizational Behavior, 25(3), 293-315. https://doi.org/10.1002/job.248

Schaufeli, W.B., Bakker, A.B., \& Van Rhenen, W. (2009). How changes in job demands and resources predict burnout, work engagement, and sickness absenteeism. Journal of Organizational Behavior, 30(7), 893-917. https://doi.org/10.1002/ job.595

Schaufeli, W.B., Salanova, M., Gonzalez-Roma, V., \& Bakker, A.B. (2002). The measurement of engagement and burnout: $A$ two sample confirmatory factor analytic approach. The Journal of Happiness Studies, 3(1), 71-92. https://doi. org/10.1023/A:1015630930326

Schaufeli, W.B., \& Taris, T.W. (2013). A critical review of the Job Demands-Resources model: Implications for improving work and health. In G. Bauer \& O. Hämmig (Eds.), Bridging occupational, organizational and public health (pp. 43-68). New York: Springer.

Schaufeli, W.B., Taris, T.W., \& Bakker, A.B. (2006). Dr. Jeckyll or Mr. Hyde: On the differences between work engagement and workaholism. In R.J. Burke (Ed.), Research companion to working time and work addiction (pp. 193-217). Cheltenham Glos, UK: Edward Elgar.

Scheines, R., Hoijtink, H., \& Boomsma, A. (1999). Bayesian estimation and testing of structural equation models. Psychometrika, 64(1), 37-52. https://doi. org/10.1007/BF02294318

Schmidt, S.W. (2007). The relationship between satisfaction with workplace training and overall job satisfaction. Human Resource Development Quarterly, 18(4), 481498. https://doi.org/10.1002/hrdq.1216

Shore, L.M., \& Tetrick, L.E. (1991). A construct validity study of the survey of perceived organizational support. Journal of Applied Psychology, 76(5), 637-643. https:// organizational support. Journal of Appli
doi.org/10.1037/0021-9010.76.5.637

Simbula, S., Guglielmi, D., \& Schaufeli, W.B. (2011). A three-wave study of job resources, self-efficacy, and work engagement among Italian school teachers. European Journal of Work and Organizational Psychology, 20(3), 285-304. European Journal of Work and Organizational
https://doi.org/10.1080/13594320903513916

Smidt, O., De Beer, L.T., Brink, L., \& Leiter, M.P. (2016). The validation of a workplace incivility scale within the South African banking industry. SA Journal of Industrial
Psychology/SA Tydskrif vir Bedryfsielkunde, 42(1), a1316. https://doi.org/10.4102/ Psychology/SATyds

Smits, S., Van Woerkom, M., \& Van Engen, M. (2012). A pro-active perspective of employees' focus on strengths and deficiencies in relation to work engagement and burnout. Unpublished master's dissertation, University of Tilburg, the Netherlands.

Sonnentag, S. (2003). Recovery, work engagement, and proactive behavior: A new look at the interface between non-work and work. Journal of Applied Psychology, 88(3), 518-528. https://doi.org/10.1037/0021-9010.88.3.518

Sonnentag, S. (2011) Research on work engagement is well and alive. European Journal of Work and Organizational Psychology, 20(1), 29-38. https://doi.org/10. 1080/1359432X.2010.510639

Sonnentag, S., Dormann, C., \& Demerouti, E. (2010). Not all days are created equal: The concept of state work engagement. In A.B. Bakker \& M.P. Leiter (Eds.), Work engagement: $A$ handbook of essential theory and research (pp. 25-38). New York: Psychology Press.

Spector, P.E. (1994). Using self-report questionnaires in OB research: A comment on the use of a controversial method. Journal of Organizational Behavior, 15(5), 385-392. https://doi.org/10.1002/job.4030150503

Stander, F.W., \& Mostert, K. (2013). Assessing the organisational and individual strengths use and deficit improvement amongst sport coaches. SA Journal of Industrial Psychology/SA Tydskrif vir Bedryfsielkunde, 39(2), 1-13. https://doi. org/10.4102/sajip.v39i2.1160

Stander, F.W., Mostert, K., \& De Beer, L.T. (2014). Organisational and individual strengths use as predictors of engagement and productivity. Journal of Psychology in Africa, 24(5), 403-409. https://doi.org/10.1080/14330237.2014.997007

Tannenbaum, S.I., Mathieu, J.E., Salas, E., \& Cannon-Bowers, J.A. (1991). Meeting trainees' expectations: The influence of training fulfillment on the development of commitment, self-efficacy, and motivation. Journal of Applied Psychology, 76(6), 759-769. https://doi.org/10.1037//0021-9010.76.6.759

Tansky, J.W., \& Cohen, D.J. (2001). The relationship between organizational support, employee development, and organizational commitment: An empirical study. Human Resource Development Quarterly, 12(3), 285-300. https://doi. org/10.1002/hrdq.15

Van de Schoot, R., Lugtig, P., \& Hox, J. (2012). A checklist for testing measurement invariance. European Journal of Developmental Psychology, 9(4), 486-492. https://doi.org/10.1080/17405629.2012.686740

Van Niekerk, G., Mostert, K., \& De Beer, L.T. (2016). Strengths use and deficit improvement: The relationship with engagement and fit with study course
amongst first-year students. Journal of Psychology in Africa, 26(1), 43-48. https:// amongst first-year students. Journal of Psycholc
doi.org/10.1080/14330237.2015.1124610

Van Woerkom, M., Mostert, K., Els, C., Bakker, A.B., De Beer, L.T., \& Rothmann, S., Jr. (2016). Strengths use and deficit correction in organizations: The development and validation of a questionnaire. European Journal of Work and development and validation of a questionnaire. European Journal of Work and
Organizational Psychology, 25(6), 960-975. https://doi.org/10.1080/135943 Organizational Psych 
Van Woerkom, M., Oerlemans, W., \& Bakker, A.B. (2015). Strengths use and work engagement: A weekly diary study. European Journal of Work and Organizational Psychology, 24(3), 384-395. https://doi.org/10.1080/135943 2X.2015.1089862

Wood, A.M., Linley, P.A., Maltby, J., Kashdan, T.B., \& Hurling, R. (2011). Using psychological strengths leads to less stress and greater self-esteem, vitality, and positive affect: Longitudinal examination of the strengths use questionnaire. Personality and Individual Differences, 50, 15-19. https://doi.org/10.1016/j. paid.2010.08.004
Wright, P., McMaham, G. \& McWilliams, A. (1994). Human resources and sustained competitive advantage: A resource-based perspective. International Journal of Human Resources Management, 5(2), 301-326. Retrieved October 31, 2016, from http://eds.a.ebscohost.com.nwulib.nwu.ac.za/ehost/detail/ detail?vid=2\&sid=c4ce964e-361d-46a9-963a-563d26550de9\%40sessionmgr401 $0 \&$ hid $=4208 \&$ bdata $=\# A N=5812660 \& d b=$ buh

Xanthopoulou, D., Bakker, A.B., Demerouti, E., \& Schaufeli, W.B. (2009). Work engagement and financial returns: A diary study on the role of job and personal resources. Journal of Occupational and Organizational Psychology, 82(1), 183200. https://doi.org/10.1348/096317908X285633 